DOI: 10.30727/0235-1188-2020-63-11-145-157

Original research paper

Оригинальная исследовательская статья

\title{
Military Ethics Education and the Changing Nature of Warfare
}

\author{
B. Višekruna
}

University of Belgrade, Belgrade, Serbia

\section{Stanar}

Union - Nikola Tesla University, Belgrade, Serbia

\begin{abstract}
This article analyzes two traditional approaches to teaching military ethics, aspirational and functionalist approach, in light of the existing technological development in the military. Introduction of new technological solutions to waging warfare that involve dehumanization, such as unmanned aerial vehicles, as well as employment of different technological tools to enhance humans participating in war and to improve military efficiency (such as built-in AI algorithms), not only bring to the surfaces the obviously existing weakness and inadequacies of the two traditional approaches to military ethics education, which have been rendered suboptimal, but also raise new challenges. The paper argues that teaching military ethics solely from the two perspective does not meet the demands of the upcoming (perhaps even already ongoing) military technological revolution and that the future will demand a more profound and conceptual moral education of military personnel that will reassess the role of martial virtues, increase responsibility for killing in war (making war more "real" and riskless killing more "difficult") and result in military professionals that resemble "a Renaissance man" in their philosophical outlook. Only by ensuring that all military professionals (in particular high-ranking officers) have been properly and adequately ethically educated, future armies, as well as entire societies, can actively aspire toward optimal armed forces structure, a more professional and efficient approach to military profession, and ultimately better and more responsible military personnel in total.
\end{abstract}

Keywords: military ethics, military ethics education, military ethos, virtue ethics, technology, unmanned military systems, dehumanization of warfare.

Bojana Višekruna (maiden Simeunovic) - Ph.D. Candidate, Research Assistant, Institute for Philosophy, Faculty of Philosophy, University of Belgrade. bojanasimeunovic5@gmail.com

Dragan Stanar - Ph.D., Associate Professor, Faculty of International Politics and Security, Union - Nikola Tesla University.

draganstanar@yahoo.com 
For citation: Višekruna B. \& Stanar D. (2020) Military Ethics Education and the Changing Nature of Warfare. Russian Journal of Philosophical Sciences $=$ Filosofskie nauki. Vol. 63, no. 11, pp. 145-157.

DOI: 10.30727/0235-1188-2020-63-11-145-157

\title{
Образование в сфере военной этики и изменение характера войн
}

\author{
Б. Вишекруна
}

Белградский университет, Белград, Сербия

\author{
Д. Станар \\ Университет «Унион - Никола Тесла», Белград, Сербия
}

\begin{abstract}
Аннотация
В настоящей статье два подхода к преподаванию военной этики мотивирующий и функциональный - рассматриваются с учетом тенденций изменения методов ведения боевых действий. Внедрение автоматизирующих технических решений при ведении военных действий - например, использование беспилотных летательных аппаратов, - равно как и использование разнообразных технических средств, позволяющих повысить эффективность человека в ходе военных действий и общую эффективность военных действий (например, встроенные алгоритмы ИИ), показывают очевидную слабость и несоответствие двух традиционных подходов к преподаванию военной этики, признанных малоэффективными, и создают новые сложности. В статье утверждается, что преподавание военной этики исключительно с применением двух подходов не соответствует требованиям грядущей (или, возможно, уже происходящей) технологической революции в военном деле, а также тот факт, что в будущем потребуется более глубокое на понятийном уровне образование военнослужащих, которое позволит переоценить роль моральных принципов военных, повысит ответственность за убийство в ходе военных действий (что сделает войну более «реалистичной», а убийство без риска - более «трудным»). Такое образование позволит сформировать у военнослужащих систему философских взглядов, близкую к «человеку эпохи Возрождения». Только за счет обеспечения надлежащего образования в области военной этики для всех военнослужащих (в частности, для старших офицеров) армии будущего и целые общества смогут направить усилия на формирование оптимальных структур вооруженных сил, реализовать более профессиональный и эффективный подход к военной деятельности и, в конечном итоге, добиться лучшего уровня подготовки и большей ответственности военнослужащих.
\end{abstract}

Ключевые слова: военная этика, преподавание военной этики, воинский этос, этика добродетели, технологии, автоматические боевые системы, обезличивание военных действий. 
Вишекруна (Сименович) Бояна - соискатель степени кандидата философских наук, научный сотрудник Института философии при философском факультете Белградского университета.

bojanasimeunovic5@gmail.com

Станар Драган - кандидат философских наук, доцент, факультет международной политики и безопасности Университета «Унион Никола Тесла».

draganstanar@yahoo.com

Для цитирования: Вишекруна Б., Станар Д. Образование в сфере военной этики и изменения характера войн // Философские науки. 2020. T. 63.№ 11. C. 145-157. DOI: 10.30727/0235-1188-2020-63-11-145-157

\section{Introduction}

At the Defense One Tech Summit in July 2017, Drew Cukor, Chief of the Algorithmic Warfare Cross-Function Team within the Office of the Undersecretary of Defense for Intelligence, announced the US military's dedication to integrate sophisticated AI technology into the existing weaponry system in order to increase its effectiveness and precision. The idea behind this AI research, also referred to as Project Maven, has been to develop the technology that would be integrated into drone systems and would provide automatic object recognition in surveillance videos. In that sense, an algorithm would correct for human error by increasing the preciseness of drone surveillance and reducing the time spent on reviewing collected video materials, essentially helping acquire accurate intelligence on the enemy's whereabouts in war zone areas. With the help of this kind of technology, as Cukor pointed, "one analyst will be able to do twice as much work, potentially three times as much, as they're doing now"; and the AI is there to complement, not replace the human operator [Pellerin, internet].

Despite its evident positive implications, technological advancement in the war industry brings to attention a number of ethical issues. We have seen that technology much less sophisticated than AI has already altered common moral dilemmas tied to the context of war and warfare. For example, with sophisticated unmanned aerial vehicles (UAVs), weapons are programmed and targets are selected by the staff on the ground, and weapons, once released, are largely autonomous [Cook 2009, 109]. The judgment of discrimination and proportionality is now partly embedded in the systems and is not solely a product of individual moral choices. This form of technology is certainly more accurate in targeting than fighter-pilots have ever been. It allows 
for the set of coordinates to be bombed with a small and managed blast effect, with limited collateral damage to both civilians and infrastructure. However, it has put pilots as those who launch weapons in an asymmetrical position, behind the controlling bars, at no risk of losing their lives whatever action they take ${ }^{1}$. This change in context resulted in the change of pilots' roles and, hence, in the change of their moral status, challenging the limits of their responsibility. One of the key questions is: Are these pilots-operators, and military staff in general, trained in a proper way to be able to make morally justified decisions in this emerging context and according to a different set of criteria? Moreover, has the current way military ethics is being taught become irrelevant in the wake of current and upcoming technological military advancement?

\section{Traditional military ethics education}

From ancient times until today, an essential component of military ethics education has been the formation of virtues, habits, military bearing, customs, and all elements of a military ethos that distinguish professional military officers from civilians [Cook 2008]. Ethos is different from ethics: whereas ethics focuses on principles that guide behavior, ethos encompasses the way in which a specific community or profession operates and lives [Deakin 2008, 21]. The aspirational approach to teaching ethics in the military focuses on ethos, a term broader and somewhat different than ethics.

As Wolfendale argues, the aim of military ethics education, according to the aspirational view, is "to cultivate good behavior through cultivation of good moral character" [Wolfendale 2008, 164]. However, she argues that the justification for such ethical training is not purely instrumental, but an end in itself. The goal is to make good people out of soldiers, by helping them develop moral capacities rather than requiring them to simply follow pre-defined rules and behave in an expected manner. Wolfendale's understanding of the role of military ethics stresses an important element of the aspirational approach: only good people make for good soldiers and what makes them good people is not merely possession of specific virtues but also behavior in accordance with those. Therefore, it is no surprise that, in majority of cases, "military ethical training emphasizes formation of strong moral character rather than sets of rules" [Schulte 2012, 110] as it is

1 They are subject to clear sanctions by the law, but this sanction is rarely lethal, meaning that they are at an equal risk like the target of losing their life. 
expected that character guarantees moral behavior. This is completely in accordance with the very notion of virtue from the perspective of virtue ethics, where virtue actually implies "a disposition or a pattern in someone's character or personality that leads them to act morally" [van Hooft_2006, 1], which means that no pre-defined rules of behavior are necessary. Still, even if soldiers are morally good people and they behave as such, they could easily be deluded with relation to why they behave in the way they do. Particularly because of that, the aspirational approach underlines the importance of soldiers reflecting on the methods that the institution employs to influence their future behavior. If it were mere instilling of virtues and behavior in accordance with those virtues, the aspirational approach would fail to acknowledge that soldiers are, after all, individual human beings.

There are two traditional problems with teaching military ethics solely in the aspirational tradition: one secondary and one fundamental. First, it is unclear whether virtues can be taught at all. Olsthoorn claims that current military education is inclined to teach about virtues in an academic setting, through case studies and sometimes role-playing, but is unable to teach virtues through practicing and repetition in real-life situations [Olsthoorn 2009]. Yet even if we were to assume that the existing practice is able to instill virtues into military professionals, a more fundamental "problem remains that virtue and ethics are not the same: virtues are about character, ethics is about conduct" [Olsthoorn 2009, 151]. Virtues alone cannot inform proper behavior in warfare. Moreover, even outside of the context of warfare, it is necessary for a person to possess practical wisdom ( $\varphi \rho \operatorname{co} \eta\rceil, \varsigma)$ in order to properly "use" virtue as a moral compass. In times of war, the significance of this practical wisdom in soldiers simply cannot be overstated. War is a very complex phenomenon and the fact that someone is a virtuous man does not guarantee that he will behave in a morally justified manner and vice versa. Lieutenant Colonel Nathan Sassaman, of the United States Army, provides us with a valuable example of how virtue-based military ethics education can yield disappointing results in reality. In his book Warrior King, Sassaman writes that his soldiers, who were accused of forcing an Iraqi civilian off a bridge into the Tigris river, not only carried a card of Army member virtues and values in their pockets but also knew them "inside and out - and in fact, strictly followed them" [Sassaman \& Layden 2008, 289]. The fact that one is a loyal soldier does not determine whether and under what circumstances it is morally justified to engage in killing an enemy's non- 
combatant. Though deadly, war is an endeavor between rational human beings, invested with ethical expectations and regulated by specific rules that are restrictive from both moral and legal points of view [Orend 2004]. Military officers need to learn, understand, and uphold those rules because these are directed toward attaining a military goal while securing a minimum standard of humane treatment in warfare. Even though it is true that virtuous people are more inclined to behave in a morally acceptable way, character shaping cannot be the only end goal of military ethics education as it provides no clear guidance on how to behave in a specific context.

Functionalist approach to teaching military ethics fills in this very gap. According to this approach, the sole goal of military ethics education is to ensure principle-guided behavior. The essence is "the transmission and perpetuation of the ethos of professionalism" that is formed out of general rules aimed at maximizing military efficiency [Wertheimer 2010, 159]. The idea is to incorporate ethics into the officers' conception of themselves as professionals with the aim of teaching them how to behave correctly when carrying out their professional duties [Kasher 2008]. The role of ethics is teaching military professionals principles and rules of proper behavior inherent to their profession. The application of these principles and rules is instrumental: they are justified as long as they lead to the highest possible level of military efficiency. That way, military efficiency becomes the end goal of ethical training in the military. As members of a specific profession, soldiers are thus completely subordinated to their organization and their actions are judged as morally justified or unjustified based on the preexisting framework of rules evaluated in terms of their contribution to victory, i.e., the highest possible level of efficiency.

One of the major shortcomings of the functionalist approach is that it puts efficiency above morality. Wolfendale claims that the functionalist view is not an ethical view at all because the end goal of teaching military ethics according to functionalists is the promotion or enhancement of military efficiency and this, as Wolfendale argues, is a non-moral concept [Wolfendale 2008, 164]. Essentially, it prescribes not morally justified behavior but "proper occupational behavior." Any kind of action that results in the achievement of military efficiency is justified, regardless of its morality. Additionally, functionalists favor no means apart from those prohibited by the professional standard; rather, any mean that is instrumentally valuable - that secures the fulfillment of the pre-defined purpose - is acceptable. In that sense, functionalists 
would not object to any form of conditioned behavior (drugs, posthypnotic suggestions or alike) that results in correct behavior serving the pre-defined purpose, i.e., military efficiency. The functionalist view, as Wolfendale infers, does not treat soldiers as autonomous rational agents "whose moral autonomy restricts how they may legitimately be treated" [Wolfendale 2008, 171].

In defense of the functionalist approach, we can say that "to be efficient" means to achieve as much as possible with as few resources as possible. Therefore, one could argue that, on the grounds of efficiency, reckless killing of military non-combatants seems to contribute very little to an efficient closing of a war in the long run. Victory as a constitutive part of war is a non-moral concept. The goal of each side in war is to win by reaching peace not justice [Babic 2019]. There is no right way to end war: what for one side is a win, for another is a loss. Therefore, it makes perfect sense to argue that if victory is a desired end to each war, then any behavior that contributes to its efficient attainment and is within the limits of professional standard could be justified on those grounds. Efficiency as a criterion can therefore limit atrocities in war. However, it still cannot solve the more fundamental problem: if the sole purpose of military professionals is to behave in a (somewhat) prescribed manner to achieve military efficiency, they still seem to be treated as less than autonomous agents.

We can conclude that both of the traditional approaches are not sufficient by themselves and should be used as complementary in the military ethics education curriculum, which is mostly the case today. However, with increasing automation of war, even when combined, these approaches fail to meet the demands of the emerging technologically advanced reality of warfare. Modern warfare brings to light two questions that challenge the very foundations of the two traditional approaches: What does it mean to be a soldier today and how does technology alter military as a profession? And the answer is clear: "Automating warfare and using military robots for a great variety of functions effectively devalues traditional military skills [and virtues] and could lead in the long term to the complete extinction of the military as a unique or at least distinct profession" [Krishnan 2009, 136]. Let us explore these observations in detail.

\section{Virtueless war(iors) and (un)functionalist approach}

No aspect of human civilization has been left unaffected by the technological revolution that is profoundly altering our lives and our 
world at an unprecedented pace. War, a perpetual shadow of human civilization has also been transformed in many ways by technology, in some perhaps even fundamentally. The way we fight wars today would be inconceivable and perhaps even unacceptable for our ancestors, whom we often celebrate as great warriors and victors. Technology enabled our generation to kill and mutilate other human beings in war without ever even setting foot on an actual battleground, without ever even being face to face with our foes. We must ask ourselves whether the very notion of a warrior is apposite for today's soldiers who increasingly resemble IT technicians more than warriors. If we were to define a warrior, we would be obliged to use moral attributes as they essentially represent a differentia specifica of the set of warriors differentiating the elements of this set from the elements of the murderers set. Virtues of courage, loyalty, honor, etc. have always been integral parts of warriors' codes, and they are still pivotal attributes of what we call soldiers today. These key martial virtues are inherent for true soldiers; they are "a part of their personal identities." [Fatic 2017, 120] These virtues are essential elements of a number of other professions and social roles as well, which are characterized by high levels of danger and crucial social responsibility that comes with the role.

What troubles us, from an ethical standpoint, is the question of these virtues in modern warfare characterized by complete spatial and partial (in cases perhaps even total) emotional detachment from the battlefield and the process of killing in war. How can one be courageous if there is literally no risk involved in his killing of another human being? What is courageous in the act of riskless remote killing via semi-autonomous weapons? Can we even conceive a warrior without courage, if we know that courage is "the martial virtue par excellence"? [Sparrow 2015, 383] It seems as though this remote and riskless killing is incompatible with the honor of military profession, that martial virtues are redundant in these scenarios. One can draw the following parallels: a fire-fighter who is prepared to put the fire down only at a safe distance does not possess true virtues of a fire-fighter; a police officer who only engages unarmed and harmless suspects is obviously deprived of key police virtues. As Walzer [1999, 6] nicely puts it: "You can't kill unless you are prepared to die" [Walzer 1999, 6]. Additionally, if a soldier is at no risk, then the distinction between combatants and non-combatants is in danger of becoming a bit blurry, because none of the two groups pose a real threat. It has been shown that not only academics and military ethicists find this entire situation problematic, but also the military itself - Sparrow explains how some 


\section{B. VISEKRUNA, D. STANAR. Military Ethics Education and the Changing Nature...}

section of the U.S. military rejected the idea of awarding prestigious medals to drone operators as they thought of them as "not really at war" [Sparrow 2015, 380]. Moreover, virtues seem utterly unimportant and simply inapplicable when we think of the relationship between a soldier/operator of a semi-autonomous weapon and the rest of his "unit" comprising of a non-animate object. Can virtues even be considered in a relationship between humans and robots?

When we discuss dehumanization in modern warfare we usually tend to refer to dehumanization of enemies that can, along with authority, "create an alarming willingness for individuals to harm others, even when they face no immediate danger to themselves" [French \& Jack 2015, 170]. We do not dispute this assertion regarding the perils of dehumanization, rather we raise a different issue: Is the process of dehumanization reserved solely for the enemy, or are technological innovations also creating an "emotional and human gap" between members of the same army? If we observe that operators of semi-autonomous weapons are becoming more and more isolated from the rest of their own troops ${ }^{2}$, we can rightfully question the bond, empathy, and cohesion between them. Naturally, an operator is fully aware of the difference between "friendlies" and hostiles on his screen, but they are all simply dots on the screen for him, pixels that have no profound and deep emotional or human meaning. They often do not even have direct communication with ground forces, and even if they do, it is conducted using digital communication platforms, without any face-to-face contact and deeper interaction. Furthermore, even the contact and relationship between operators working in the same base is quite different than what is usually understood as martial comradeship, as they do not depend on each other, they do not place their lives in each other's hands, they do not share the feeling of lethal danger and primal fear, which is so characteristic for people in combat. All the things that are necessary for the existence of the proverbial "band of brothers,"3 so essential for military ethos, are simply missing. Detachment from battle and enemies, combined with the lack of danger, risk, and shared experience, erodes not only unit cohesion and empathy, but also the

2 Operators sit in high-tech control centers, usually isolated in containers and small rooms filled with screens, with absolutely no personal contact with the on-ground forces they are providing support to.

3 Even in Shakespeare's famous St Crispin's Day Speech (where the term "Band of brothers" was forged), Henry V only considers those who "shed their blood with him" worthy of becoming his brothers [Shakespeare 1914, 84]. 
cornerstones of the unique military ethos. The increase of non-human factors in military operations gives rise to new ethical challenges and questions the validity of virtue-based warrior identity of soldiers.

In a survey conducted by Mental Health Advisory Team IV under the project Operation Iraqi Freedom 05-07, a third of both soldiers and marines deployed in Iraq reported facing moral dilemmas in combat to which they did not know how to respond [Mental Health Advisory Team IV, 2006]. They all received training in battlefield ethics; however, because of a shift in the nature of warfare and the complexity of context in the Iraqi war, their training proved to be not entirely relevant. Rules and codes of conduct work in a rule-bound environment that is defined by hierarchy, both hierarchy in values and hierarchy of rank - such were symmetric wars of the $20^{\text {th }}$ century. The $21^{\text {st }}$ century asymmetric conflicts, like those in Afghanistan and Iraq, had brought those exact rules into question, and the introduction of unmanned systems has made them almost redundant in the new emerging context. Introduction of network-centric warfare and a shift toward virtual, rather than face-to-face, communication have loosened the military hierarchy. Some drone operators explained that in most cases communication via digital platforms creates confusion, as it allows for simultaneous online presence of people with different military ranks. Sometimes, soldiers do not know who they are talking to and whose command they should follow [Singer 2009, 513]. Moreover, geographical detachment from the battlefield has brought into question the definition of a combatant itself, in a more profound way than that was the case with the emergence of irregular warfare. Operating unmanned systems from their cubicles, after finishing their shifts, soldiers retreat to their normal life, picking up their kids from school and having dinner with their family. It would be counterintuitive to argue that they are legitimate targets even after their shift, and that is exactly what the current definition of a combatant would suggest. When the context drastically changes, the rules and principles need to adapt as well.

Perhaps a conclusion can be drawn from this, that every functionalist approach in ethics is destined to fail if it neglects to readapt its rules and principles to the emerging context - what and why is morally obligatory, permissible, or forbidden - but also if it fails to address the necessary understanding of what and why is done. This new emerging context dictates that we teach our soldiers higher philosophical concepts and the fundamental nature of moral demands and moral behavior. Never before in history has it been more important to insist on deeper 
understanding of moral principles in the military, as technological progress enabled militaries to be extremely efficient in what they do, in performing their function. New moral dilemmas of soldiers caught up in a high-technology warfare will demand profound and conceptual moral education, not simply cookie-cutter ethical programs with lists of demands and abstract values that serve to achieve maximum efficiency with minimum resources.

\section{Conclusion}

Military profession is undergoing significant change, and it is paramount for military ethics to keep pace with these changes and adapt accordingly. Military ethics education must evolve in such a way that it transcends the traditional approach, yet preserving both the functionalist and virtue-ethics component in the process. Soldiers of the future will perhaps resemble gamers more than traditional warriors, but that does not mean that the killing they will do will be any less real or morally challenging. One of the main goals of ethical education of future soldiers will be to make the killing more "real," more personal and more "difficult." At first glance, it may seem a bit counter-intuitive to think that we must strive to make killing more "difficult" for our own soldiers, but it will be a counter-balance to the historically unparalleled easiness of taking lives made possible by modern military technology. Increased feeling of responsibility for killing must be instilled in those who will in future kill much less personally than ever before. Virtue of courage in war will also need to be readdressed and perhaps even redefined in order to emphasize the significance of what is called moral courage. This element is much lacking in modern armies that are currently "no bastions of moral courage" [Olsthoorn 2011, 53]. As Mark Mandeles argues, future militaries will require "'renaissance men' who have wide knowledge of natural and social sciences, computers, and software (and who can 'shoot')" (as cited in: [Krishnan 2009, 136]). Perhaps this paradigm shift in the nature of warfare even opens the door for a much bigger role of deontology and absolutistic prohibitions in the study of military ethics. Perhaps the unbearable easiness of killing in the future will enable us to establish some type of a consequentialism threshold ${ }^{4}$ at which absolutely no amount of military advantage could justify killing.

4 As opposed to the deontological threshold "at which the prohibition against murder is overridden" [Nagel 1979, 62]. 


\section{REFERENCES}

Babić J. (2019) Ethics of War and Ethics in War. Conatus. Vol. 4, no. 1, pp. 9-30.

Cook M. (2008) Ethics Education, Ethics Training, and Character Development: Who 'Owns' Ethics in the US Air Force Academy? In: Robinson P., de Lee N., \& Carrick D. (Eds.) Ethics Education in the Military (pp. 57-65). Hampshire: Ashgate.

Cook M. (2009) Teaching Military Ethics in the United States Air Force: Challenges Posed by Service Culture. In: Robinson P., Connelly J., \& Carrick D. (Eds.) Ethics Education for Irregular Warfare (pp. 107-118). Hampshire: Ashgate.

Deakin S. (2008) Education in an Ethos at the Royal Military Academy Sandhurst. In: Robinson P., de Lee N., \& Carrick D. (Eds.) Ethics Education in the Military (pp. 15-29). Hampshire: Ashgate.

French S. \& Jack A. (2015) Dehumanizing the Enemy: The Intersection of Neuroethics and Military Ethics. In: Whetham D. \& Strawser B.J. (Eds.) Responsibility to Protect: Perspectives in Theory and Practice (pp. 169195). Boston: Brill-Nijhoff.

Kasher A. (2008) Teaching and Training Military Ethics: An Israeli Experience. In: Robinson P., de Lee N., \& Carrick D. (Eds.) Ethics Education in the Military (pp. 133-145). Hampshire: Ashgate.

Krishnan A. (2009) Killer Robots. Hampshire: Ashgate.

Mental Health Advisory Team IV, Operation Iraqi Freedom 05-07 (2006) Final Report. Retrieved from http://www.combatreform.org/MHAT_IV_ Report_17NOV06.pdf

Nagel T. (1979) Mortal Questions. Cambridge: Cambridge University Press.

Olsthoorn P. (2009) Ethics Education for Operations Other Than War: The Dutch Approach. In: Robinson P., Connelly J., \& Carrick D. (Eds.) Ethics Education for Irregular Warfare (pp. 145-158). Hampshire: Ashgate.

Olsthoorn P. (2011) Military Ethics and Virtues: An Interdisciplinary Approach for the $21^{\text {st }}$ Century. Burlington: Routledge.

Orend B. (2004) Kant's Ethics of War and Peace. Journal of Military Ethics. Vol. 3, no. 2, pp. 161-177.

Pellerin C. (2017) Project Maven To Deploy Computer Algorithms to War Zone By Year's End. DOD News. Retrieved from https://www.defense. gov/News/Article/Article/1254719/project-maven-to-deploy-computeralgorithms-to-war-zone-by-years-end/

Sassaman N. \& Layden J. (2008) Warrior King: The Triumph and Betrayal of an American Commander in Iraq. New York: St. Martin's Press. 
Schulte P. (2012) Morality and War. In: Lindley-French J. \& Boyer Y. (Eds.) The Oxford Handbook of War (pp. 99-115). Oxford: Oxford University Press.

Shakespeare W. (1914) Henry V. New York: American Book Company. Singer P.W. (2009) Wired for War. London: The Penguin Press.

Sparrow R. (2015) Drones, Courage, and Military Culture. In: Lucas G. (Ed.) Routledge Handbook of Military Ethics (pp. 380-395). Burlington: Routledge.

van Hooft S. (2006) Understanding Virtue Ethics. Slough: Acumen Publishing Limited.

Walzer M. (1999) Kosovo. Dissent. Vol. 46, no. 3, pp. 5-7.

Wertheimer R. (2010) The Morality of Military Ethics Education. In: Wertheimer R. (Ed.) Empowering Our Military Conscience: Transforming Just War Theory and Military Moral Education (pp. 159-196). Burlington: Routledge.

Wolfendale J. (2008) What is the Point of Teaching Military Ethics? In: Robinson P., de Lee N., \& Carrick D. (Eds.) Ethics Education in the Military (pp. 161-174). Hampshire: Ashgate. 